\title{
Mobile Marketing in Business Sustainability: A Bibliometric Analysis
}

\author{
Wan Mohd Hirwani Wan Hussain, Norzalita Abdul Aziz \\ Graduate School of Business, Universiti Kebangsaan Malaysia, Bangi, Selangor, Malaysia
}

\begin{abstract}
The rising of mobile marketing in business is gaining attention from the small medium business to corporate level. The purpose of this paper is to review the literature on the topic "mobile marketing" from 2010 to 2020. This study can be used as the benchmarking analysis to obtain deeper understanding about mobile marketing. The study analyzed 373 articles published in Web of Science database that contains more than 20,500 peer reviewed journal. The most influential and highly cited academic papers, universities, countries and peer-reviewed academic journal were considered in this study. This study can provide an overview of the current state of research in mobile marketing strategy and practices. This study can serve as the strategy for potential research in the future and understanding mobile marketing through visualization methods.
\end{abstract}

Keywords - Camera Web of Science, VOSviewer, Bibliometric review, Business Sustainability, Visualization Strategy.

\section{Introduction}

The rising of the internet create an impact for the marketing to the customer. Over the years, marketing has evolved from mass marketing to the personalized marketing that targeted specific customer segmentation.

DOI: $10.18421 /$ TEM111-13

https://doi.org/10.18421/TEM111-13

Corresponding author: Wan Mohd Hirwani Wan Hussain, Graduate School of Business, Universiti Kebamgsaan Malaysia, Bangi, Selangor, Malaysia.

Email: wmhwh@ukm.edu.my

Received: 07 July 2021.

Revised: 03 December 2021.

Accepted: 10 December 2021.

Published: 28 February 2022.

(c) BY-NC-ND (C) 2022 Wan Mohd Hirwani Wan Hussain \& Norzalita Abdul Aziz; published by UIKTEN. This work is licensed under the Creative Commons AttributionNonCommercial-NoDerivs 4.0 License.

The article is published with Open Access at www.temjournal.com
In year 1970s, most of the banking industry began to adopt the Electronic Funds Transfer (EFT) that can manage the transaction within the network. In the year 2008, the rising of blockchain technology create big impact to the financial institutions that has to address the customer needs. The business has to ensure their sustainability and also their ability to survive based on the latest technology been implemented in the market.

Digital transformation has become of the important criteria for business sustainability. From the first website launched in 1990 to over a billion website by 2020, the growth of this revolution has grown at a breakneck pace. Small and Medium enterprises in Malaysia often believe that the rising of advances in website and mobile platform will transform and boost the business sustainability. Malaysian consumers' use of smartphones continues to grow, according to [1]. This medium enables marketers to not only communicate with consumers in real time, but also to tailor ad messages based on their geographic location.

Additionally, mobile marketing increases the likelihood that the advertisement message will reach the intended audience. It has become increasingly critical for small and medium-sized businesses to leverage as it has evolved into a critical mode of communication, transaction, and shopping.

The capability of mobile marketing platform can provide innovative and creative solution that integrate to the specific business needs. This can ensure the best strategy to generate leads to the business. Most of the researcher agrees that mobile platform is a new way to communicate [2], create a new business [3] managing and understanding the new market [4], and also teaching [5]

Mobile marketing can enable marketers to leverage this method of advertising's distinct characteristics in order to more precisely target consumers' needs [6]. This phenomenon has compelled marketers to engage in mobile media marketing activities. Effective marketing management emphasises the importance of developing long-term relationships with customers and retaining their loyalty.

Smart mobile devices are multi-purpose ubiquitous devices that rest largely on the major activities that 
application use offers [7]. Applications (apps) are software that enable smart devices to deliver specific mobile services such as navigation and mapping. For tourism industry mobile advertising are expected to generate profit through the mobile technology by reducing costs and market awareness plus promotion strategy. Mobile marketing also gain attention in tourism because it can help in assist a destination by reducing cost and administration and also manage the customers database for promotion materials. Additionally, mobile marketing's business have the potential to support small medium enterprise (SME) in the future compared to other marketing [8], and more than half of the world's population will own at least one mobile device. Thus, mobile marketing contributes to the achievement of the aforementioned marketing management objectives in a variety of ways, as it enables both parties to participate in communication processes between marketer and consumer. Numerous studies on mobile marketing have demonstrated that this marketing tool can be extremely effective in terms of brand building and eliciting a response from customers; thus, it can be concluded that mobile marketing increases brand attitude and purchase intentions. Additionally, mobile marketing has demonstrated a high level of attention, as messages are typically read in their entirety and frequently immediately upon receipt [9].

\section{Background Study}

SMEs are critical to the country's economic development, and most of the country around the world depends on their SMEs to develop and sustain their economic well-being. In today's globalized environment, SMEs face numerous challenges, including a lack of financing, low productivity, a lack of managerial capabilities, and limited access to management and technology. Most of the Malaysian SMEs are still heavily reliant on the domestic market and face additional challenges in terms of market access, technological advancement, innovation and creativity, access to information, and human development. Malaysia has adopted a standardized definition of SMEs to make it easier to identify them across sectors and subsectors.

Even though there are a considerable number of researches on mobile marketing, there are not many studies on the understanding trends and future patterns of mobile marketing for business sustainability. Understanding mobile marketing adoption is critical for the communication industry because marketers are leveraging this technology to get closer to their customers. Today, advertising is ubiquitous, and as the advertising marketplace becomes extremely competitive, it becomes increasingly difficult to capture customers' attention.
Most customers use mobile apps every day to their daily needs, such as making a purchase, socializing with their friends, and making payments for their needs. The rising of Vblog app TikTok rose the second most download mobile in 2020 with more than 30 million active users in the United States. Mobile payment becomes increasingly popular because it offers fast payment, more secure and convenient to the customer [10].Giant companies such as Apple, Alibaba, and Google already launched their mobile payment gateway by promoting their own mobile wallet that can be convenient for customers to shop and engage with their mobile devices.

Mobile marketing has risen to prominence as one of the most popular e-commerce applications. As mobile technologies become more widely adopted globally, international mobile marketing becomes a growing concern. Research done by [11] suggest that additional research in other developing countries is necessary to understand mobile marketing adoption better. Numerous studies have discovered that customers adopt mobile marketing on a utilitarian basis. There are still relatively few studies that examine manager adoption of mobile marketing and its effect on performance.

The term and definition "mobile" are beyond the original definition, which only related to portable mobile devices and services. Mobile marketing technology enables small business to interact effectively with their customers. Based on the definition by [12] Mobile Marketing Association defines mobile marketing as "sending advertising messages to mobile devices such as mobile phones or PDAs through the wireless networks." It is noteworthy to mention that, even though the terms wireless advertising and mobile advertising are used as synonymic terms by many authors, there are also few academic papers where most of the definition or descriptions which refer to traditional advertising. Mobile marketing is a very powerful medium that links customers directly to the companies.

In addition to branding opportunities, advertisers can also employ a variety of response mechanisms. This is possible due to sending text, picture, audio or video messages to the user directly from the phone. In addition to the benefits mentioned earlier of personalization and location-awareness, it is also possible to send interactive communications. Most of SMEs want to adopt this new marketing approach. This requires a new form of intervention at the management level to understand the potential of mobile marketing for their business sustainability. Based on the research by [13], SMEs' attitude and knowledge are the most important determinants of mobile marketing acceptance in Malaysia, followed by branding strategy and technical knowledge. 
Marketing is a critical commercial application, and managerial support is crucial in technology adoption. It is must be accepted by the management level the importance of this technology before it can proceed to the marketing process. According to Mobile marketing instruments ( $\mathrm{m}$-marketing) enable novel forms of customer relationship and interaction and will result in the development of a plethora of mobile commerce-based services.

As customers spend more time on mobile devices for their daily tasks and need, it is worthwhile to examine how marketers can drive these new marketing channels for their business sustainability. Research done by [14] understand the potential of microblogging for mobile devices, and based on their research, it shows that microblogging will increase the click-through rates by more than $37 \%$. The important of digital marketing also been adopted a their in-store shopping journey [15]. Then research by Wang et. al experimented to understand the paid keyword in mobile marketing. They concluded that mobile marketing could contribute to higher sales than other online channels such as search engine marketing, website marketing, video marketing and social media marketing.

In addition, mobile marketing strategy also can be incorporated with environmental studies such as weather [16] and also in agriculture business [17]. For mobile marketing in weather, mobile marketing can provide information for the customers about the weather conditions before making their purchase.

Understanding the principle of "mobile marketing" is rapidly changing. Most of the marketing channels incorporate digital elements in their strategy, and marketers must be aware of this new type of strategy. The landscape for marketing and digital will evolve as new things are invented. This paper will address the potential of future-forward research in mobile marketing that can become the main criteria in digital marketing for business sustainability.

\section{Research Questions}

This study used papers indexed by the Web of Science Database. The research questions are as follows:

RQ1: What areas of mobile marketing have been investigated most often based on research publications?

Answering RQ1 allowed for the identification of valuable future research directions.

RQ2: What has been the statistical distribution of mobile marketing publications and citations in recent years?
The answer to RQ2 can provide the yearly volume of mobile marketing publications and citations that can understand based on Web of Science Database.

RQ3: What are the most influential papers on mobile marketing?

Answering RQ3 can provide insights into which papers on mobile marketing are frequently referred to in the literature. Knowing this will help identify the types of studies and methodologies that contribute to high-quality research on the subject.

RQ4: Which institutions and countries provide the most support for research on mobile marketing?

The answer to this question can identify opportunities for research collaborations related to mobile marketing.

RQ5: What are the currently popular research topics and emerging trends in mobile marketing research?

The answer to RQ5 can enable the identification of future research directions.

\section{Methodology}

The Web of Science database was used to obtain the articles for this study. Other scientific databases, such as Scopus, Medline, and Google Scholar, were considered, but Web of Science was chosen because it is the best resource for identifying emerging trends, it increases the researcher's visibility, it fosters collaboration between researchers, and it provides a strong strategic position for the organization and university. Additionally, the Web of Science Database is structured in such a way that it facilitates bibliometric analysis, and the Web of Science Database is massive; it contains more than 37,500 peer-reviewed journals [18], conference proceedings, and books on a variety of subjects including life sciences, social sciences, physical sciences, and health sciences.

The key words "mobile marketing" were used to initiate the process of extracting papers from Web of Science, and the search was limited to English language studies for 10 years which is between 2010 and 2020. Based on Figure 1, the search returned a total of 373 papers. Article (230) were the most frequently published form of text, accounting for $61.67 \%$ of total publications. Next is Proceedings Paper which is the second-most frequent at $34.05 \%$ (127), followed by Book Chapter conference reviews (28), Editorial Material (10), Review (5), Book Review (4), Early Access (3), correction (1) and data paper (1). The numbers and proportions of the different document types are shown in Table 1. All documents were downloaded in tab separator format on June $8^{\text {th }}, 2021$. 


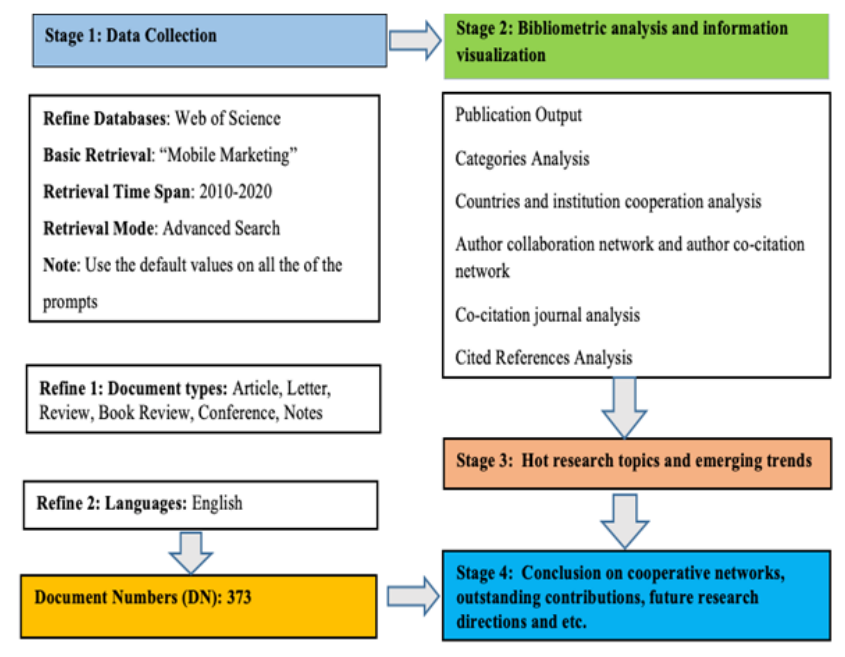

Figure 1. Stage of Bibliometric Analysis on Mobile Marketing using Web of Science Database

The publication's quality was determined using bibliometric analysis, which provided the data for the visualization. This is critical for researchers and organizations at the university or practitioners from industry. For researchers, bibliometric indicators provide an overview of a study and the impact of articles published in a particular journal on the scientific community, enabling them to choose the best journal for submission. For universities and academic organizations, bibliometric indicators enable them to assess the quality of a researcher, a research group, or a specific study, thereby assisting them in making decisions about promotions, appointments, and research grant allocation.

Table 1. Types of documents retrieved

\begin{tabular}{lcc}
\hline \multicolumn{1}{c}{ Types of document } & Frequency & Proportion (\%) \\
\hline Article & 230 & 61.67 \\
\hline Proceedings Paper & 127 & 34.05 \\
\hline Book Chapter & 28 & 7.57 \\
\hline Editorial Material & 10 & 2.69 \\
\hline Review & 5 & 1.34 \\
\hline Book Review & 4 & 1.07 \\
\hline Early Access & 3 & 0.80 \\
\hline Correction & 1 & 0.27 \\
\hline Data Paper & 1 & 0.27 \\
\hline \multicolumn{1}{c}{ Total } & $\mathbf{3 7 3}$ & $\mathbf{1 0 0}$
\end{tabular}

Bibliometric co-citation analysis is a type of analysis that identifies and recognize the relationship between the research articles and related topics. This type of analysis provides an understanding about the topic of research study. When applying this technique, the pattern and trends will emerge from the research topics and this will provide valuable information for new research. Science mapping is the crucial steps in the bibliometrics study that can provide the current research topics development. The term bibliometrics mapping can be refers to the relationship between the discipline of research, country, regions, university and faculty. The study of bibliometric study was introduced by Allen Richard in 1969 to replace statistical bibliography and since then, there are many topics done related on this bibliometric research. There are several software packages that can be used as the bibliometrics analysis and in this paper, we will use VOS Viewer software from the Centre for Science and Technology Studies, Leiden University, Leiden, The Netherlands. It should be noted that VOS viewer is widely used in bibliometric analysis, especially in thematic, cartographic, and cluster analysis. Bibliometrics enables the academic analysis of citations, co-citations, geographical distribution, and word frequency in the literature in a specific area of research to provide useful conclusions.

\section{Results}

The results of this study are presented in five parts. The first section discusses the current distribution of literature related to mobile marketing, and the second section considers the distribution of journals publishing studies on mobile marketing. The third section focuses on an analysis of the keywords used in the research on mobile marketing, and the fourth section gives information on the contributions to the field by country. The last section considers the most highly cited studies on mobile marketing.

\section{a. The Distribution of Studies on Mobile Marketing}

The Texas A\&M University has contributed most to the research on mobile marketing with 7 publications. Next, Bogazici University and University of Gloucestershire share the second position, with 6 publications each. Then Sichuan University (China), University of Minho (Portugal), University of Presov (Slovakia) each contributed 5 publications while Istanbul Bilgi University (Turkey), Northeastern University (United States), University of Manchester (United Kingdom) and Temple University (United States) published 4 publications on mobile marketing.

There are fewer than 100 papers from the top 10 institutions, which suggests that research related to mobile marketing is still an infancy state.

Table 2. Top Organization published on mobile marketing

\begin{tabular}{clccc}
\hline Rank & Organization & Publication & Frequency & Country \\
\hline $\mathbf{1}$ & $\begin{array}{l}\text { Texas A \& M } \\
\text { University }\end{array}$ & 7 & 1.87 & $\begin{array}{c}\text { United } \\
\text { States }\end{array}$ \\
\hline $\mathbf{2}$ & $\begin{array}{l}\text { Bogazici } \\
\text { University }\end{array}$ & 6 & 1.61 & Turkey \\
\hline $\mathbf{3}$ & $\begin{array}{l}\text { University of } \\
\text { Gloucestershire }\end{array}$ & 6 & 1.97 & $\begin{array}{c}\text { United } \\
\text { Kingdom }\end{array}$ \\
\hline
\end{tabular}




\begin{tabular}{clccc}
\hline $\mathbf{4}$ & $\begin{array}{l}\text { Sichuan } \\
\text { University }\end{array}$ & 5 & 1.72 & China \\
\hline $\mathbf{5}$ & $\begin{array}{l}\text { University of } \\
\text { Minho }\end{array}$ & 5 & 1.72 & Portugal \\
\hline $\mathbf{6}$ & $\begin{array}{l}\text { University of } \\
\text { Presov }\end{array}$ & 5 & 1.48 & Slovakia \\
\hline $\mathbf{7}$ & $\begin{array}{l}\text { Istanbul Bilgi } \\
\text { University }\end{array}$ & 4 & 1.48 & Turkey \\
\hline $\mathbf{8}$ & $\begin{array}{l}\text { Northeastern } \\
\text { University }\end{array}$ & 4 & 1.48 & $\begin{array}{c}\text { United } \\
\text { States }\end{array}$ \\
\hline $\mathbf{9}$ & $\begin{array}{l}\text { University of } \\
\text { Manchester }\end{array}$ & 4 & 1.48 & $\begin{array}{c}\text { United } \\
\text { Kingdom }\end{array}$ \\
\hline $\mathbf{1 0}$ & $\begin{array}{l}\text { Temple } \\
\text { University }\end{array}$ & 4 & 1.23 & $\begin{array}{c}\text { United } \\
\text { States }\end{array}$ \\
\hline
\end{tabular}

\section{b. The Distribution of Project funded Studies on Mobile Marketing}

Table 3 shows that the National Natural Science Foundation of China contributed to 10 sponsored projects related to mobile marketing; this is followed by the European Commission which sponsored 7 projects and followed by Ministry of Science and Technology at Taiwan for 4 projects. China focus research on mobile marketing because the rising of mobile application in their country and they want to champion in the digital economy revolution. The famous company from China such as Alibaba, Taobao, Tencent and TikTok established their mobile application to capture the customer attentions and seize the market share [19].

Table 3. Top 10 institutions providing funding for studies on mobile marketing

\begin{tabular}{|c|c|c|c|}
\hline Rank & Organizations & $\begin{array}{l}\text { Sponsor } \\
\text { Project }\end{array}$ & Country \\
\hline 1 & $\begin{array}{l}\text { National Natural Science } \\
\text { Foundation of China }\end{array}$ & 10 & China \\
\hline 2 & European Commission & 7 & Europe \\
\hline 3 & $\begin{array}{l}\text { Ministry of Science and } \\
\text { Technology }\end{array}$ & 4 & Taiwan \\
\hline 4 & $\begin{array}{l}\text { National Science } \\
\text { Foundation NSF }\end{array}$ & 4 & $\begin{array}{l}\text { United } \\
\text { States }\end{array}$ \\
\hline 5 & $\begin{array}{l}\text { Norte Portugal Regional } \\
\text { Programme }\end{array}$ & 4 & Portugal \\
\hline 6 & $\begin{array}{l}\text { Portuguese Foundation } \\
\text { for Science \& } \\
\text { Technology }\end{array}$ & 4 & Portugal \\
\hline 7 & $\begin{array}{l}\text { Fundamental Research } \\
\text { Project FRP for Central } \\
\text { Universities }\end{array}$ & 3 & $\begin{array}{l}\text { United } \\
\text { States }\end{array}$ \\
\hline 8 & $\begin{array}{l}\text { National Research } \\
\text { Foundation of Korea }\end{array}$ & 3 & Korea \\
\hline 9 & $\begin{array}{l}\text { Vedecka Grantova } \\
\text { Agentura (VEGA) }\end{array}$ & 3 & Slovakia \\
\hline 10 & $\begin{array}{l}\text { Ministry of Education } \\
\text { Culture Sports Science } \\
\text { Japan Mext }\end{array}$ & 2 & Japan \\
\hline
\end{tabular}

Then on Table 4, it shows the information about the top 10 journals published in mobile marketing. Based from the table, it shows that Journal of Interactive Marketing ranks highest publication related to mobile marketing with 15 publications, followed by International Journal of Mobile Communications and Journal of Research in Interactive Marketing with 14 publications. The frequency of publications on mobile marketing, as shown in Table 4, suggests that the number of published articles related to mobile marketing in these journals is still low compared to other disciplines such as social media marketing, digital marketing or search engine marketing.

Table 4. Journals publishing articles on mobile marketing

\begin{tabular}{|c|c|c|c|}
\hline Rank & Journal & $\begin{array}{c}\text { Publication } \\
\text { Record }\end{array}$ & Frequency \\
\hline 1 & $\begin{array}{l}\text { Journal of Interactive } \\
\text { Marketing }\end{array}$ & 15 & 4.02 \\
\hline 2 & $\begin{array}{l}\text { International Journal } \\
\text { of Mobile } \\
\text { Communications }\end{array}$ & 14 & 3.75 \\
\hline 3 & $\begin{array}{l}\text { Journal of Research in } \\
\text { Interactive Marketing }\end{array}$ & 14 & 3.75 \\
\hline 4 & $\begin{array}{l}\text { E-Marketing } \\
\text { Concepts } \\
\text { Methodologies Tools } \\
\text { \& Applications }\end{array}$ & 13 & 3.48 \\
\hline 5 & $\begin{array}{l}\text { Journal of Retailing \& } \\
\text { Consumer Services }\end{array}$ & 11 & 2.94 \\
\hline 6 & $\begin{array}{l}\text { International Journal } \\
\text { of Information } \\
\text { Management }\end{array}$ & 6 & 1.61 \\
\hline 7 & $\begin{array}{l}\text { Advanced Science } \\
\text { Letters }\end{array}$ & 5 & 1.34 \\
\hline 8 & Business Horizons & 5 & 1.34 \\
\hline 9 & $\begin{array}{l}\text { Journal of Business } \\
\text { Research }\end{array}$ & 5 & 1.34 \\
\hline 10 & $\begin{array}{l}\text { Journal of Product \& } \\
\text { Brand Management }\end{array}$ & 5 & 1.34 \\
\hline
\end{tabular}

Next, we will look at the network visualization. Figure 2 shows the network visualization and density visualization of the citation analysis using VOSviewer, revealing five journals that dominated the research related to mobile marketing: a) Journal of Interactive Marketing, b) Journal of Research in Interactive Marketing, c) International Journal of Information Management, d) Business Horizons Journal, and e) Journal of Retailing \& Consumer Services. Based from the analysis, Journal of Interactive Marketing was also the journal most frequently cited in mobile marketing studies; thus, Journal of Interactive Marketing plays a significant part in the advancement of the study of mobile marketing. 

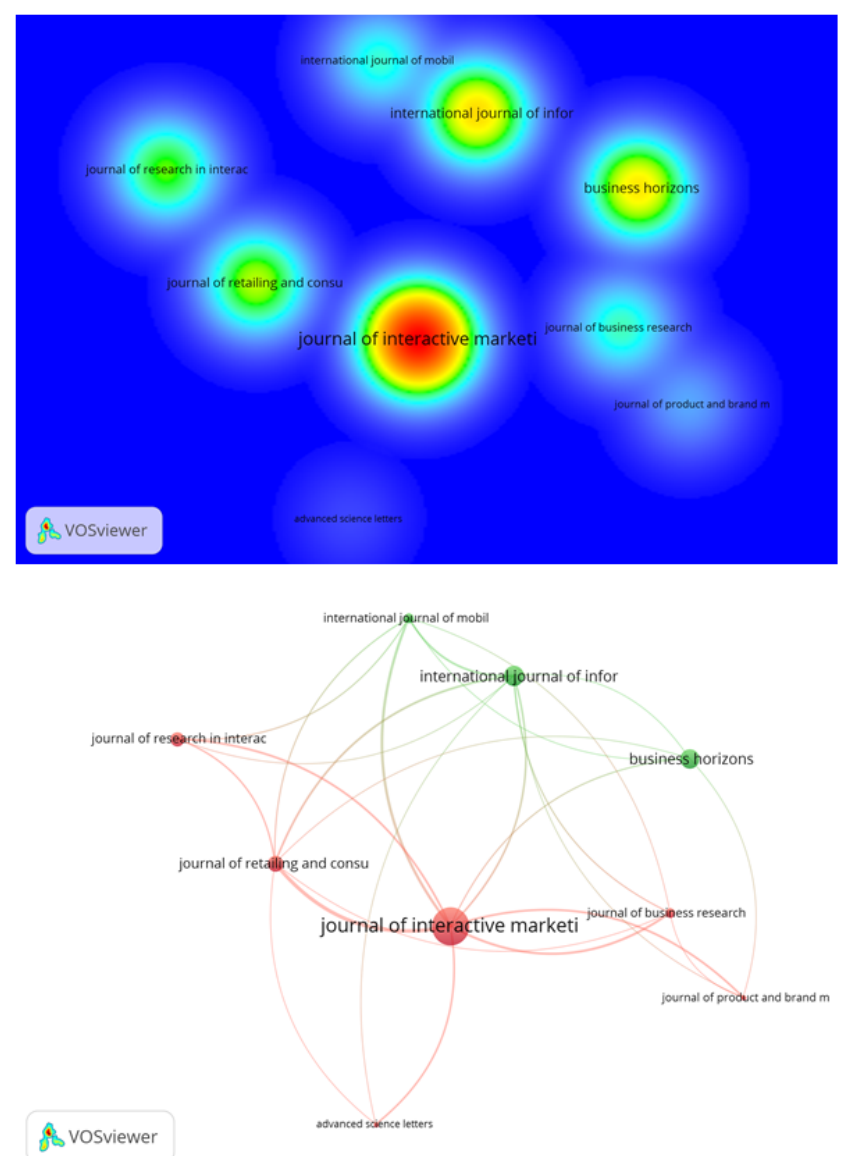

Figure 2. Analysis of the citations of articles on mobile marketing based on the journal in which they are published

\section{c. Analysis of Keywords in Popular Research Areas in Mobile Marketing Studies}

This section discusses keyword co-occurrence by analyzing the distribution of keywords based on information from the Web of Science Database. A keyword co-occurrence map and keyword density view provide an overview of the keywords that appear in the literature and can be used to identify the research hotspot areas in a field, which is, in this case, the study of mobile marketing [20]. Based on 373 mobile marketing related publications, 1445 keywords were identified; this study considered only keywords that appeared at least five times. Figure 3 shows the keyword occurrence, as given by a VOSviewer analysis. There were two clusters divided, and the keyword "mobile marketing" was shown to be most frequently used at 199. Other keywords that occurred frequently included a) mobile advertising, b) social media, c) digital marketing, and d) smart phone. The distance between two nodes indicates the strength of their relationship; in general, a shorter distance indicates a stronger relationship [21].

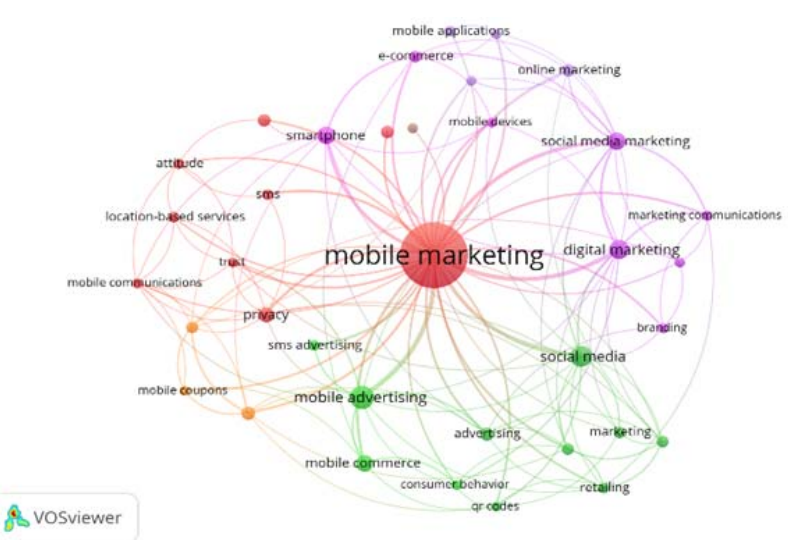

Figure 3. Keywords co-occurrence network of mobile marketing system-related

Table 5. Top 10 most frequently used keywords in mobilemarketing related publications

\begin{tabular}{clcc}
\hline Rank & \multicolumn{1}{c}{ Keywords } & Frequency & $\begin{array}{c}\text { Total link } \\
\text { strength }\end{array}$ \\
\hline 1 & Mobile Marketing & 199 & 193 \\
\hline 2 & Mobile Advertising & 26 & 35 \\
\hline 3 & Social Media & 20 & 31 \\
\hline 4 & Digital Marketing & 18 & 38 \\
\hline 5 & Smartphone & 14 & 33 \\
\hline 6 & Mobile Commerce & 14 & 22 \\
\hline 7 & Privacy & 13 & 14 \\
\hline 8 & Consumer Behavior & 11 & 13 \\
\hline 9 & Advertising & 9 & 17 \\
\hline 10 & Online Marketing & 9 & 14 \\
\hline
\end{tabular}

VOS viewer software can also visualize keyword density. Figure 4 shows the keyword density based on each node. Red indicates a higher occurrence of the word in the research then words surrounded by green. Density views provide a useful understanding of the overall structure of mapping and drawing in visualization research [22].

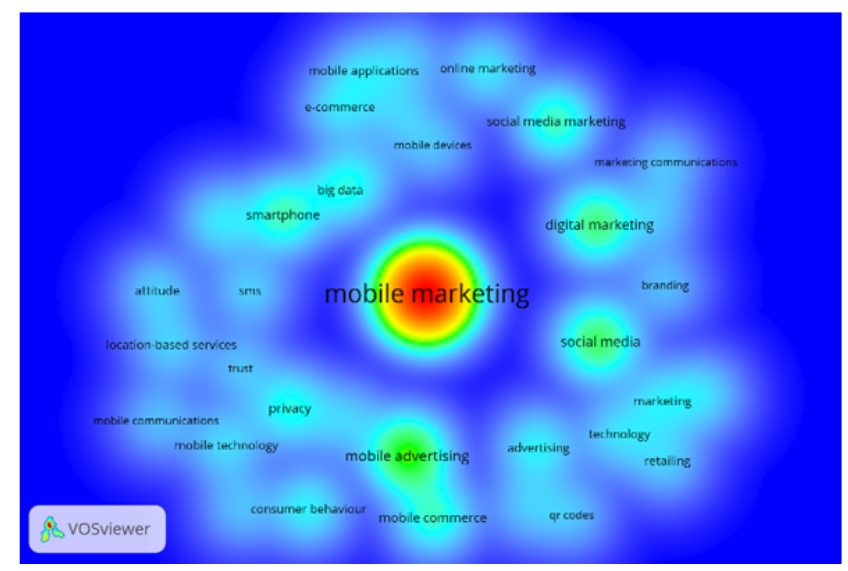

Figure 4. Keyword density visualization map of publications on mobile marketing 


\section{d. Analysis of Research on Mobile Marketing by Country and Co-Authorship}

Country co-authorship was used to understand the degree of communication between countries and to identify the influential countries in this field. In Figure 5, the colors represent the nodes, which show the diversification of research directions. The bigger the node in the network, the greater the contribution of the country. The United States, China, England, Turkey and South Korea are the most influential in this area of research in mobile marketing. The United States primarily collaborates with the South Korea, Turkey, Germany, Canada and France. China collaborates with Netherlands and Taiwan collaborates with Malaysia. This analysis shows that geography also plays an important role in research and publication.

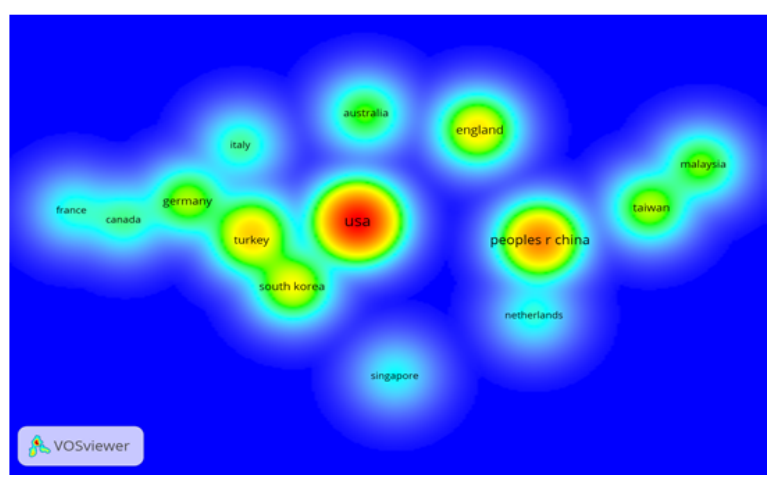

Figure 5. The country co-authorship network of mobile marketing-related publications

Based on Table 6 lists the countries that have published articles related to mobile marketing. The United States dominates the list with 95 documents and 2419 citations, followed by England (26) with 820 citations. China has published 48 documents with 564 citations, followed by the Canada (8), Australia (13), Taiwan (17), Germany (16), Turkey (21), Netherlands (6), and South Korea (22). This data can provide a benchmark for mobile marketingrelated research for other countries.

Table 6. The top 10 country with the highest citations related mobile marketing

\begin{tabular}{lccc}
\hline \multicolumn{1}{c}{ Country } & Document & Citations & $\begin{array}{c}\text { Total link } \\
\text { strength }\end{array}$ \\
\hline United States & 95 & 2419 & 296 \\
\hline England & 26 & 820 & 138 \\
\hline China & 48 & 564 & 114 \\
\hline Canada & 8 & 245 & 31 \\
\hline Australia & 13 & 238 & 50 \\
\hline Taiwan & 17 & 216 & 53 \\
\hline Germany & 16 & 206 & 72 \\
\hline Turkey & 21 & 197 & 40 \\
\hline Netherlands & 6 & 192 & 59 \\
\hline South Korea & 22 & 189 & 41 \\
\hline
\end{tabular}

\section{e. Most Often Cited Mobile Marketing-related Publications}

Based on the Table 7 shows the paper written by [23] title Mobile Marketing in the Retailing Environment: Current Insights and Future Research Avenues receive the highest citation with 262 . This paper explains about the important of mobile marketing for retailing environment and what the future-forward. Then paper by [4] explains about the revolution of mobile marketing from 2005 to 2015 and give the suggestion for the future agenda. The paper ranked third is by [24] that address effectiveness of mobile application for the consumers. Most of the papers are related to mobile marketing related to potential of mobile marketing and the impact of customers for business in the future.

Table 7. The top 10 highly cited papers written in mobile marketing

Title Journal

$\begin{array}{lllll}\begin{array}{l}\text { Mobile Marketing in } \\ \text { the Retailing }\end{array} & \begin{array}{l}\text { Journal of } \\ \text { Interactive }\end{array} & \text { [23] } & 2010 & 262 \\ \begin{array}{llll}\text { Environment: Current } \\ \text { Insights and Future }\end{array} & \begin{array}{l}\text { Marketing } \\ \text { Resion }\end{array} & & & \end{array}$

Research Avenues

A Thematic Exploratior

of Digital, Social

Media, and Mobile

Marketing: Research

Evolution from 2000 to

Journal of

Marketing

[4] $2016 \quad 252$

2015 and an Agenda for

Future Inquiry

$\begin{array}{lllll}\text { The Effectiveness of } & \text { Journal of } & & & \\ \begin{array}{l}\text { Branded Mobile } \\ \text { Phone Apps }\end{array} & \begin{array}{l}\text { Interactive } \\ \text { Marketing }\end{array} & \text { [24] } & 2011 & 170\end{array}$

Phone Apps

Marketing

If you love

something, let it go

mobile: Mobile

marketing and mobile

Business

Horizons [25] $2012 \quad 147$

social media $4 \times 4$

Geo-Conquesting:

Competitive

Locational Targeting

of Mobile Promotions

Mobile marketing
research: The-state-
of-the-art.

Journal of

Marketing

Research

[26] $2015 \quad 116$

International

Journal of

Information

[27] $2010 \quad 116$

of-the-art.

Management

Gamification and Journal of

Issues, Current

[29] $2016 \quad 114$
Mobile Marketing Interactive

Effectiveness Marketing

Mobile Shopper

Marketing: Key

Journal of
Interactive

Marketing
[28] $2016 \quad 114$

Research Avenues 


\begin{tabular}{|c|c|c|c|c|}
\hline $\begin{array}{l}\text { Estimating Demand } \\
\text { for Mobile } \\
\text { Applications in the } \\
\text { New Economy }\end{array}$ & $\begin{array}{c}\text { Management } \\
\text { Science }\end{array}$ & [14] & 2014 & 110 \\
\hline $\begin{array}{l}\text { Innovative mobile } \\
\text { marketing via } \\
\text { smartphones Are } \\
\text { consumers ready? }\end{array}$ & $\begin{array}{c}\text { Marketing } \\
\text { Intelligence \& } \\
\text { Planning }\end{array}$ & [30] & 2012 & 107 \\
\hline
\end{tabular}

\section{Future Research}

Based on our analysis on the extant literature studies on Web of Science Database. We can offer a forward-looking outlook on potential topics related to mobile marketing in the near future. The rising of Industrial Revolution IR 4.0 provides more intelligence and connected mobile devices that can understand customer psychological needs. This is important because the customer is more complicated and with the support from Artificial Intelligence, the marketers and researchers can gain more understanding about customers that they are not able to understand from the past technology.

This study provides valuable information on mobile marketing-related publications using bibliometric analysis and visualization. This information can be summarized as follows: First, most of the mobile marketing research and publication is dominated by the United States and China. Thus, the United States is the bellwether in this field of study. In terms of institutions, the National Natural Science Foundation of China has sponsored the highest number of projects related mobile marketing. The Texas A \& M University from United States has contributed most to the literature on mobile marketing

The influential journal in mobile marketing is Journal of Interactive Marketing and International Journal of Mobile Communications and get most of the citations from researchers. Based on the Web of Science there are less than 500 papers related to mobile marketing and this can be used as the indicator to shows that the research in this are still new and can be further expand in the future.

Second, based on a keyword analysis, mobile marketing-related publications focus on strategic directions and the important of this marketing strategy for business. This study also suggest that there are many potential research agenda that can be further study such as gamification, artificial intelligence, chatbots application and many more.

Third, the emerging trends in mobile marketing identified using VOSviewer provide an overview of the focus of research related to mobile marketing.

This study also had some limitations. The scope of this paper included only English peer-reviewed papers collected from Web of Science Database; thus, this study should be expanded to include other databases, such as the Scopus, Pub line, Ebscohost, and CSSCI, to gain a more thorough understanding of mobile marketing related research.

\section{Conclusion}

Research on mobile marketing can contribute to the emergence of new subjects for future research. Mobile marketing research and studies are always concerned with carefully addressing trust and privacy issues [2]. This study identified the following emerging issues that should be considered in future studies: artificial intelligence [31], cloud computing [32], mobile channels, Internet of Things (IoT) [33], big data marketing [34] and machine learning in mobile marketing [35] .

\section{Acknowledgement}

This work was supported by research grants FRGS/1/2020/SS01/UKM/02/2, and RHB-UKM-2020-003 under the Ministry of Higher Education, Malaysia and RHB Endowment Fund. The author would also like to thank the Graduate School of Business, UKM under grant GSB 2021-018, for supporting this study.

\section{References}

[1]. SKMM. (2017). "Suruhanjaya Komunikasi Dan Multimedia Malaysia Malaysian Communications and Multimedia Commission Hand Phone Users Survey," Evol. Media Commun., vol. Statistica.

[2]. Eneizan, B., Mohammed, A. G., Alnoor, A., Alabboodi, A. S., \& Enaizan, O. (2019). Customer acceptance of mobile marketing in Jordan: An extended UTAUT2 model with trust and risk factors. International Journal of Engineering Business Management, 11, 1847979019889484.

[3]. Huq, M. M., Farhana, K., \& Rahman, A. (2017). Application of mobile phone in agricultural marketing in bangladesh. IOSR J. Bus. Manag, 19(1), 77_82.

[4]. Lamberton, C., \& Stephen, A. T. (2016). A thematic exploration of digital, social media, and mobile marketing: Research evolution from 2000 to 2015 and an agenda for future inquiry. Journal of Marketing, 80(6), 146-172.

[5]. Buzdar, A. Q., \& Farooq, M. (2020). Memorization of Quran through Mobile Application in the Era of Transformative Marketing. Pakistan Journal of Social Sciences (PJSS), 40(2), 689-698.

[6]. Tong, S., Luo, X., \& Xu, B. (2020). Personalized mobile marketing strategies. Journal of the Academy of Marketing Science, 48(1), 64-78.

[7]. Aliaño, Á. M., Hueros, A. D., Franco, M. G., \& Aguaded, I. (2019). Mobile learning in university contexts based on the unified theory of acceptance and use of technology (UTAUT). Journal of New Approaches in Educational Research (NAER Journal), 8(1), 7-17.

[8]. Roux, T., Mahlangu, S., \& Manetje, T. (2020). Digital signage as an opportunity to enhance the mall environment: a moderated mediation model. International Journal of Retail \& Distribution Management. 
[9]. Hayward, K. L., Martin, J. H., Cottrell, W. N., Karmakar, A., Horsfall, L. U., Patel, P. J., ... \& Valery, P. C. (2017). Patient-oriented education and medication management intervention for people with decompensated cirrhosis: study protocol for a randomized controlled trial. Trials, 18(1), 1-13.

[10]. Vrontis, D., Thrassou, A., \& Amirkhanpour, M. (2017). B2C smart retailing: A consumer-focused value-based analysis of interactions and synergies. Technological Forecasting and Social Change, 124, 271-282.

[11]. Tarhini, A., Alalwan, A. A., Shammout, A. B., \& Al-Badi, A. (2019). An analysis of the factors affecting mobile commerce adoption in developing countries: Towards an integrated model. Review of International Business and Strategy, 29(3), 157-179.

[12]. Oscar, R. P., Alexandra, M. L., \& Sandra, R. B. (2017). Mobile marketing: conceptualization and research review. Espacios, 38(61), 1-26.

[13]. Musa, H., Li, S. C. H., Abas, Z. A., \& Mohamad, N. (2016). Adoption factor of mobile marketing: The case of small medium enterprises in Malaysia. International Review of Management and Marketing, 6(7S), 112-115.

[14]. Ghose, A., \& Han, S. P. (2014). Estimating demand for mobile applications in the new economy. Management Science, 60(6), 1470-1488.

[15]. Besbes, O., Gur, Y., \& Zeevi, A. (2016). Optimization in online content recommendation services: Beyond click-through rates. Manufacturing \& Service Operations Management, 18(1), 15-33.

[16]. Ma, J., Huang, D., \& Wang, Y. (2021). The congruent and comparative impacts of weather on consumer reviews: evidence from an online forum and experiment. International Journal of Internet Marketing and Advertising, 15(1), 54-83.

[17]. Kassem, H. S., Alotaibi, B. A., Ghoneim, Y. A., \& Diab, A. M. (2020). Mobile-based advisory services for sustainable agriculture: Assessing farmers' information behavior. Information Development, 0266666920967979.

[18]. Zhu, J., \& Liu, W. (2020). A tale of two databases: the use of Web of Science and Scopus in academic papers. Scientometrics, 123(1), 321-335.

[19]. Kennedy, M. (2020). 'If the rise of the TikTok dance and e-girl aesthetic has taught us anything, it's that teenage girls rule the internet right now': TikTok celebrity, girls and the Coronavirus crisis. European Journal of Cultural Studies, 23(6), 1069-1076.

[20]. Khiste, G. P., \& Paithankar, R. R. (2017). Analysis of Bibliometric term in Scopus. International Journal of Library Science and Information Management (IJLSIM), 3(3), 81-88.

[21]. Cicea, C., \& Marinescu, C. (2021). Bibliometric analysis of foreign direct investment and economic growth relationship. A research agenda. Journal of Business Economics and Management, 22(2), 445466.
[22]. Marsh, S. E. (2020). Making Connections and Measuring Performance: Bibliometric Analysis of Multi-Attribute, Preference-Based Health-Related Quality of Life Research in South Africa. Value in Health Regional Issues, 22, 99-107.

[23]. Shankar, V., Venkatesh, A., Hofacker, C., \& Naik, P. (2010). Mobile marketing in the retailing environment: current insights and future research avenues. Journal of interactive marketing, 24(2), 111120 .

[24]. Bellman, S., Potter, R. F., Treleaven-Hassard, S., Robinson, J. A., \& Varan, D. (2011). The effectiveness of branded mobile phone apps. Journal of interactive Marketing, 25(4), 191-200.

[25]. Kaplan, A. M. (2012). If you love something, let it go mobile: Mobile marketing and mobile social media 4x4. Business horizons, 55(2), 129-139.

[26]. Fong, N. M., Fang, Z., \& Luo, X. (2015). Geoconquesting: Competitive locational targeting of mobile promotions. Journal of Marketing Research, 52(5), 726-735.

[27]. Varnali, K., \& Toker, A. (2010). Mobile marketing research: The-state-of-the-art. International journal of information management, 30(2), 144-151.

[28]. Hofacker, C. F., De Ruyter, K., Lurie, N. H., Manchanda, P., \& Donaldson, J. (2016). Gamification and mobile marketing effectiveness. Journal of Interactive Marketing, 34, 25-36.

[29]. Shankar, V., Kleijnen, M., Ramanathan, S., Rizley, R., Holland, S., \& Morrissey, S. (2016). Mobile shopper marketing: Key issues, current insights, and future research avenues. Journal of Interactive Marketing, 34, 37-48.

[30]. Persaud, A., \& Azhar, I. (2012). Innovative mobile marketing via smartphones: Are consumers ready?. Marketing Intelligence \& Planning,30(4), 418-443.

[31]. Yau, K. L. A., Saad, N. M., \& Chong, Y. W. (2021). Artificial Intelligence Marketing (AIM) for Enhancing Customer Relationships. Applied Sciences, 11(18), 8562.

[32]. Chen, W., Pei, Y., Wang, X., Ma, C., Wang, Z., \& Zhu, W. (2015, November). A Data Collection and Analysis System for Mobile Group Marketing. In 2015 International Conference on Cloud Computing and Big Data (CCBD) (pp. 223-230). IEEE.

[33]. Juska, J. M. (2017). Integrated Marketing Communication: Advertising and Promotion in a Digital World. Nova Southeastern University, United States: Taylor and Francis.

[34]. Ojha, S. C. (2019). Big data: a new perspective for the establishment of segments for niche marketing. International Journal of Business Excellence, 19(3), 381-393.

[35]. Peyravi, B., Nekrošienè, J., \& Lobanova, L. (2020). Revolutionised technologies for marketing: theoretical review with focus on artificial intelligence. Business: Theory and Practice, 21(2), 827-834. 